\title{
SARS-CoV-2 and liver damage: a possible pathogenetic link
}

\author{
Ludovico Abenavoli ${ }^{1}$, Ivan Gentile ${ }^{2,3}$, Alberto Enrico Maraolo ${ }^{4}$, Francesco Negro ${ }^{5}$ \\ ${ }^{1}$ Department of Health Sciences, University Magna Graecia, Catanzaro, Italy; ${ }^{2}$ Department of Clinical Medicine and Surgery, Section of Infectious \\ Diseases, ${ }^{3}$ Member of UNESCO Chair on Health Education and Sustainable Development, University of Naples "Federico II", Naples, Italy; ${ }^{4}$ First \\ Division of Infectious Diseases, Cotugno Hospital, AORN dei Colli, Naples, Italy; ${ }^{5}$ Divisions of Gastroenterology and Hepatology and of Clinical \\ Pathology, Geneva University Hospitals, Geneva, Switzerland \\ Correspondence to: Ludovico Abenavoli, MD. PhD. Department of Health Sciences, University "Magna Graecia”, Viale Europa, 88100, Catanzaro, \\ Italy. Email: 1.abenavoli@unicz.it. \\ Provenance and Peer Review: This article was not commissioned by the editorial office, Hepatobiliary Surgery and Nutrition. The article did not undergo \\ external peer review.
}

Submitted Apr 20, 2020. Accepted for publication May 07, 2020.

doi: $10.21037 / \mathrm{hbsn}-20-437$

View this article at: http://dx.doi.org/10.21037/hbsn-20-437

On December 31, 2019, the World Health Organization (WHO) China Country Office, was informed of pneumonia cases of unknown etiology detected in Wuhan, a city of Hubei Province in China. On January 9, 2020, China Center for Disease Control and Prevention (CDC) reported that the causative agent of this outbreak was a novel coronavirus (2019-nCoV), phylogenetically in the SARS$\mathrm{CoV}$ clade (1). The official names announced for the virus responsible of this infection and the related disease were severe acute respiratory syndrome coronavirus 2 (SARSCoV-2) and COVID-19 respectively (2,3). On 11 March, WHO stated that the outbreak might be uncontrolled and announced that COVID-19 could be defined as a pandemic $(4,5)$. As of May 12, 2020, 4,178,346 cases of COVID-19 were reported worldwide in more than 187 countries and regions, with 286,355 total confirmed deaths (6). However, these data are being constantly updated on international data resources.

Nowadays, there are still important questions to answer. In particular, to better understand the current pandemic is mandatory to analyze the mechanisms that SARS$\mathrm{CoV}-2$ employs to infect humans and cause disease. Over the last weeks, some evidence that liver injury occurred in COVID-19 patients has emerged (7).

During the early stage of the disease, it mainly manifested in terms of mild to moderate elevation of transaminases levels (8). Some subjects had increased serum bilirubin and decreased serum albumin levels and hepatic impairment has been reported to be more prevalent in severe than in mild cases. Also, in the patients with SARS-CoV-2 infection is reported a dysregulation of coagulative and fibrinolytic pathways, probably due to the overactivation of innate immune response with excessive and uncontrolled cytokines release with subsequent hyperinflammation status (9).

The incidence of liver injury, according to literature data are variable, and ranged from $14.8 \%$ to $53 \%$ (7). From a hepatologist's point of view, this scenario opens a pivotal question: is the liver directly affected by the viral replication or is the organ damage secondary to other causes, such as the host immune reaction to the infection or to the drugs used for the infection treatment?

According to limited published data, postmortem liver biopsy specimens of patients with COVID-19, showed moderate microvesicular steatosis and mild lobular and portal activity (10). These histological findings seem to suggest a direct cytotoxic effect of the virus and/or or a drug-induced liver injury. However, on the basis of current scientific literature, is possible to hypothesize that the development of liver disease in COVID-19 patients, might be related to any of these pathogenetic processes: (I) a direct action of the virus against the liver; (II) systemic inflammation associated to "cytokines storm"; (III) acute hepatic decompensation in patients with long-standing preexisting liver disease; (IV) hypoxic liver damage due to an imbalance between organ oxygen supply (compromised by respiratory failure) and demand; as well as (V) druginduced liver injury, associated with the use of hepatotoxic therapies. 
About the first point, the presence of the virus in the stool, may suggest an important role of the hepatobiliary tract as a hub for viral replication and excretion into the gastrointestinal tract (11). Of note, the expression of angiotensin-converting enzyme 2 (ACE-2) receptor, the main target of the virus for cell entry, seems to be expressed in cholangiocytes, that could be the site wherein the virus replicates and therefore dysregulate liver function (12). Nevertheless, viral inclusion have not been observed in liver cells (10).

Also, many of the repurposed drugs against SARS-CoV-2 may be hepatotoxic: for instance, in one study involving 148 Chinese patients, new-onset abnormal liver function after admission and therapy commencement was higher in the group undergoing lopinavir/ritonavir treatment (13). At any rate, alterations typical of liver damage, as well as elevated alanine aminotransferase level, reduced platelet counts and reduced albumin level at the time of admission, have been associated with higher death rate, but it is not clear if they are linked with pre-existing liver disease or if they are a consequence of viral action (13). If people with comorbidities, including cardiovascular disorders or diabetes, are at higher risk of a severe course of COVID-19, the same reasoning may apply to patients with liver disease (14). To this aim, a position paper by authoritative societies has been issued as for the care of patients with liver disease during COVID-19 pandemic (15). Further studies are necessary to clarify the pathogenetic mechanisms of liver involvement in patients with COVID-19, in order to define an effective therapeutic strategy.

\section{Acknowledgments}

Funding: None.

\section{Footnote}

Conflicts of Interest: All authors have completed the ICMJE uniform disclosure form (available at https://hbsn. amegroups.com/article/view/10.21037/hbsn-20-437/coif). IG reports personal fees from MSD, personal fees from Correvio, personal fees from Pfizer, personal fees from Angelini, personal fees from Nordic, personal fees from Abbvie, grants from Gilead Sciences, outside the submitted work. The other authors have no conflicts of interest to declare.

Ethical Statement: The authors are accountable for all aspects of the work in ensuring that questions related to the accuracy or integrity of any part of the work are appropriately investigated and resolved.

Open Access Statement: This is an Open Access article distributed in accordance with the Creative Commons Attribution-NonCommercial-NoDerivs 4.0 International License (CC BY-NC-ND 4.0), which permits the noncommercial replication and distribution of the article with the strict proviso that no changes or edits are made and the original work is properly cited (including links to both the formal publication through the relevant DOI and the license). See: https://creativecommons.org/licenses/by-nc-nd/4.0/.

\section{References}

1. World Health Organization. Middle East respiratory syndrome coronavirus (MERS-CoV) - MERS situation update, January 2020. Available online: http://www.emro. who.int/health-topics/mers-cov/mers-outbreaks.html

2. Zhu N, Zhang D, Wang W, et al. A Novel Coronavirus from Patients with Pneumonia in China, 2019. N Engl J Med 2020;382:727-33.

3. Zhang T, Wu Q, Zhang Z. Probable Pangolin Origin of SARS-CoV-2 Associated with the COVID-19 Outbreak. Curr Biol 2020;30:1346-51.e2.

4. WHO Director-General's opening remarks at the media briefing on COVID-19 - 11 March 2020. Available online: https://www.who.int/dg/speeches/detail/who-directorgeneral-s-opening-remarks-at-the-media-briefing-oncovid-19---11-march-2020

5. Abenavoli L, Cinaglia P, Luzza F, et al. Epidemiology of Coronavirus Disease Outbreak: The Italian Trends. Rev Recent Clin Trials 2020. [Epub ahead of print].

6. Johns Hopkins Coronavirus Resource Center. Updated May 12, 2020. Available online: https://coronavirus.jhu. edu/map.html

7. Zhang J, Wang S, Xue Y. Fecal specimen diagnosis 2019 novel coronavirus-infected pneumonia. J Med Virol 2020. [Epub ahead of print].

8. Sun J, Aghemo A, Forner A, et al. COVID-19 and liver disease. Liver Int 2020. [Epub ahead of print].

9. Li J, Fan JG. Characteristics and Mechanism of Liver Injury in 2019 Coronavirus Disease. J Clin Transl Hepatol 2020;8:13-7.

10. Xu L, Liu J, Lu M, et al. Liver injury during highly pathogenic human coronavirus infections. Liver Int 2020;40:998-1004. 
11. Xu Z, Shi L, Wang Y, et al. Pathological findings of COVID-19 associated with acute respiratory distress syndrome. Lancet Respir Med 2020;8:420-2.

12. Chai X, Hu L, Zhang Y, et al. Specific ACE2 Expression in Cholangiocytes May Cause Liver Damage After 2019-nCoV Infection. bioRxiv 2020 doi: 10.1101/2020.02.03.931766

13. Zhou F, Yu T, Du R, et al. Clinical course and risk factors for mortality of adult inpatients with COVID-19 in Wuhan, China: a retrospective cohort study. Lancet

Cite this article as: Abenavoli L, Gentile I, Maraolo AE, Negro F. SARS-CoV-2 and liver damage: a possible pathogenetic link. HepatoBiliary Surg Nutr 2020;9(3):322-324. doi: 10.21037/hbsn-20-437
2020;395:1054-62.

14. Yang J, Zheng Y, Gou X, et al. Prevalence of comorbidities and its effects in coronavirus disease 2019 patients: A systematic review and meta-analysis. Int J Infect Dis 2020;94:91-5.

15. Boettler T, Newsome PN, Mondelli MU, et al. Care of patients with liver disease during the COVID-19 pandemic: EASL-ESCMID position paper. JHEP Rep 2020;2:100113. 